\author{
A.A. Sarsembayeva1 iD, K.M. Nagymzhanova ${ }^{2 *}$ iD, \\ L.S. Baimanova ${ }^{3}$ \\ ${ }^{1}$ D. Serikbayev East-Kazakhstan technical university, Kazakhstan, Ust-Kamenogorsk \\ ${ }^{2}$ «Turan-Astana» University, Kazakhstan, Nur-Sultan \\ ${ }^{3}$ Ualikhanov University, Kazakhstan, Kokshetau \\ *e-mail:karakat_4@mail.ru
}

\title{
STUDENT MULTILINGUAL COMPETENCE FORMATION AT A TECHNICAL UNIVERSITY
}

The article focuses on the problem of the formation of multilingual competence of engineering students. The concept of "multilingualism" is considered from the standpoint of practical knowledge of one or more foreign languages, if English is the first FL, and German, French, Turkish and Chinese - as the second FL. In the context of the internationalization of professional education and professional activity, the presence of multilingual competence is defined as one of the leading supra-professional competencies of an engineering graduate. The article describes the requirements of the leading international engineering communities for certification and registration of specialists in terms of multilingualism.

The article describes the requirements of the leading international engineering communities for certification and registration of specialists from the point of view of multilingualism. The practice of organizing the process of multilingual education in a non-linguistic university is presented by D. Serikbayev East Kazakhstan Technical University where the main forms and techniques aimed at developing the multilingual competence of students are considered.

Key words: multilingualism, language training at the university, level training, language module.

\author{
А.А. Сарсембаева ${ }^{1}$, К.М. Нагымжанова²*, ^.С. Байманова ${ }^{3}$ \\ '^А. Серікбаев атындағы Шығыс Қазақстан техникалық университеті, Қазақстан, Өскемен қ. \\ 2«Тұран-Астана» университеті, Қазақстан, Нұр-Сұлтан қ. \\ ${ }^{3}$ Ш. Уәлиханов атындағы Көкшетау мемлекеттік университеті, Қазақстан, Көкшетау қ. \\ *e-mail: karakat_4@mail.ru \\ Техникалық жоғары оқу орны жағдайларында \\ студенттердің көптімдік құзыреттілігін қалыптастыру
}

Мақала инженерлік мамандықта оқитын студенттердің көптілді құзыреттілігін қалыптастыру мәселесіне арналған. «Көптілділік» ұғымы ағылшын тілін бірінші шетел тілі, неміс, француз, түрік және қытай тілдерін екінші шетел тілі ретінде меңгерген жағдайда бір немесе бірнеше шет тілдерін практикалық меңгеру тұрғысынан қаралады. Кәсіби білім беру мен кәсіби қызметтің интернационаландыру жағдайында көптілді құзіреттіліктің болуы инженерлік бағыттағы жоғары оқу орны түлегінің жетекші кәсіби құзіреттілігінің бірі ретінде анықталаАы. Ұлттық мәдениет пен студенттердің мәдениетаралық қарым-қатынас ерекшеліктерін ескере отырып, техникалық жоғары оқу орындары студенттерінің көптілді құзіреттілігін қалыптастыру мәселесі жоғары оқу орындарының алдына оны шешудің келісілген кешенді тәсілдемесін іздеу қажеттілігін қояды. Авторлардың пікірінше, дұрыс таңдалған мазмұны мен ақпараттық мазмұны бар шет тілдерін оқытудың әртүрлі нысандары мен әдістерін қолдану арқылы жалпы мәдени құзыреттіліктердің қалыптасу деңгейінің оқытылатын шет тілдерінің санына тікелей тәуелділігі бар.

Мақалада жетекші халықаралық инженерлік қауымдастықтардың көптілділік тұрғысынан мамандарды сертификаттау және тіркеу талаптары сипатталған. Тілдік емес ЖОО-да көптілді оқыту процесін ұйымдастыру тәжірибесі $А$. Серікбаев атындағы Шығыс Қазақстан техникалық университетінің тәжірибесінде ұсынылған, студенттердің көптілді құзыреттілігін дамытуға бағытталған негізгі нысандары мен әдістері қарастырылды.

Түйін сөздер: көптілділік, ЖОО-дағы тілдік дайындық, деңгейлік оқыту, тілдік модуль. 


\author{
А.А. Сарсембаева ${ }^{1}$, К.М. Нагымжанова ${ }^{2 *}$, ^.С. Байманова ${ }^{3}$ \\ 'Восточно-Казахстанский технический университет им. А. Серикбаева, Казахстан, г. Усть-Каменогорск \\ ${ }^{2}$ Университет «Туран-Астана», Казахстан, г. Нур-Султан \\ ${ }^{3}$ Кокшетауский университет им. Ш. Уалиханова, Казахстан, г. Кокшетау \\ ${ }^{*}$ e-mail:karakat_4@mail.ru \\ Формирование мумьтиязычной компетенции студентов \\ в условиях технического вуза
}

\begin{abstract}
Статья посвящена проблеме формирования мультиязычной компетенции студентов инженерных специальностей. Понятие «мультиязычности» авторы рассматривают с позиции практического владения одним или несколькими иностранными языками при условии владения английским языком как первым ИЯ, немецким, французским, турецким и китайским языками - как вторым иностранным языком. В условиях итернационализации профессионального образования и профессиональной деятельности наличие мультиязычной компетенции определяется как одна из ведущих надпрофессиональных компетенций выпускника вуза инженерной направленности. Проблема формирования полиязычной компетентности студентов технических вузов с учетом национальной культуры и особенностей межкультурного общения студентов ставит вузы перед необходимостью поиска согласованного комплексного подхода к ее решению. По мнению авторов, существует прямая зависимость уровня сформированности общекультурных компетенций от количества изучаемых иностранных языков за счет использования различных форм и методов обучения иностранным языкам с правильно подобранным содержанием и информационным наполнением.

В статье охарактеризованы требования ведущих международных инженерных сообществ Аля сертификации и регистрации специалистов с точки зрения мультиязычности. Практика организации процесса мультиязычного обучения в неязыковом вузе преАставлена на опыте Восточно-Казахстанского технического университета имени А.Серикбаева, рассмотрены основные формы и приемы, направленные на развитие мультиязычной компетенции студентов.

Кмючевые слова: мультиязычность, языковая подготовка в вузе, уровневое обучение, язЫковой МОАуль.
\end{abstract}

\section{Introduction}

Currently, an engineer must know several foreign languages, possess multilingual competence, and this is due to the constantly operating technology market. In the era of globalization, it is impossible to isolate and base the industry only on its technologies, since they are bought, sold, and adapted, they are always interconnected, and even if an employee of the company does not work abroad, he/ she must be able to compose, read, translate and navigate instructions and accompanying technical documentation.

The main factors contributing to the formation of a multilingual and multicultural educational environment in universities in Kazakhstan are:

1) attraction of foreign students, 2) development of students'academic mobility of technical universities, 3) development of international academic programs, 4) internationalization of students scientific activities, 5) participation in international educational and scientific projects, 6) expansion of publication geography, 7) the number of university graduates, building their careers in international companies, organizations and international recognition of Kazakhstani diplomas (Bologna process).
The problem of the formation of students' multilingual competence of technical universities, taking into account the national culture and the peculiarities of intercultural communication among students, puts universities in front of the need to search for a coordinated integrated approach to its solution.

First, the need to reckon with the real possibilities of both university and school education led to the realization of setting a more realistic and pragmatic goal of multilingual education, which can be defined not as training specialists with the same competence in several languages, but as ensuring the level of knowledge of one or another a language that meets one or another communicative, pragmatic and other needs of the learners, and which, after the end of the training period can be improved if necessary.

The next aspect of the implementation of the principles of multilingual education associated with the need to create a unified system of teaching languages, involves the creation of coordinated curricula that takes into account the aspects of learning the native language, as a factor that forms a unified system of learning several foreign languages. The native language, thus, turns out to be the basis and a certain starting point in the formation of the general linguistic competence of an individual, and the 
study of subsequent foreign languages expands and deepens this competence giving it a new quality and new properties.

\section{Materials and methods}

An important aspect of the implementation of multilingual methods of teaching languages is the problem of creating educational materials for nonlinguistic universities. We are talking about the creation of comparative textbooks which should include grammatical and conversational topics of the target language, correlating with topics from the relevant field, covered in the study of the previous (foreign) or native language. Studying the material based on such aids will allow the teacher to rely on the previous linguistic and cognitive experience of the learners, as well as to draw the necessary sociocultural parallels.

The contradiction between the internal desire to realize one's national identity and the need to realize oneself in a multicultural community, as well as the requirement to understand the national and cultural context of partner countries and the specifics of work in industries in other countries in the modern labour market conditions which arises among students during the entire period of study at the university requires the development of new approaches to solving the problem of adaptation and interaction in a multicultural educational and professional space.

Research objectives:

- toconsider the concept of "multilingualism" in the context of modern engineering education;

- to analyze the requirements for the professional qualifications of engineers from national and international communities from the perspective of multilingualism;

- to substantiate the ways of integrating the English language into professional education;

- describe the practice of organizing multilingual education at a technical university.

Research methods:

- to study the theoretical and methodological foundations of teaching languages and form a theoretical basis for the study, theoretical analysis and generalization of data from scientific and methodological literature are used;

- to study the existing system of teaching languages in non-linguistic universities, an analysis of the educational documentation of higher education and the study and generalization of pedagogical experience is used;

- to implement the main approaches to the formation of multilingual competence, a pedagogical experiment, pedagogical observation, questioning was carried out; the analysis of the experimentally obtained data is carried out by methods of mathematical data processing.

\section{Literature Review}

A significant contribution to the study of multilingualism as a pedagogical and methodological problem in educational institutions was made by such scientists as N.V. Baryshnikov (simultaneous study of four foreign languages), L.M. Malykh and A.V. Zhukova (model of multilingual education in a polyethnic region), A.A. Prokhorov (formation of students' multilingual competence of engineering specialities) $[1,2,3]$. According to these scientists, in the process of simultaneous or sequential study of several foreign languages, multilingual communicative competence is formed. The study of the phenomenon of multilingualism as a social phenomenon was most fully reflected in the studies of V.F.Gabdulkhakov, A.N.Dzhurinsky, N.V.Evdokimova, B.R.Mogilevich, V.M.Smotkin and others $[4,5,6]$.

Such scientists as J. Blommaert, R. Franceschini, Li Wei and others [7,8] pay special attention to the definition of the essence and concept of multilingualism. The process of formation of sociocultural competence in the process of professional training is reflected in the works of E.A.Zhezher, N.G.Muravyova, Yu.A. Kustov, D.N.Mashkov, I.V.Gruzdev [9]; the socio-cultural aspect in the formation of general cultural (universal) and professional competencies through a foreign language is disclosed in the works of N.D. Galskova, J. Duarte, and K. Shabani.

The works of domestic and foreign scientists such as K.N. Bulatbaeva, Z.K. Akhmetzhanova, Sh. Kurmanbayuly, A. Amirkhamzin, IliufHadjiMurad, N.V. Baryshnikov, V.V. Lazarev, B.A. Zhetpisbaeva, T.T. Abdukadyrova, Ya.M. Kolker, R.K. MinyarBelorucheva, I.I. Zhinkina, A.C. Smagulova, A.B. Raisova and others [10] are devoted to theoretical questions on the problems of bilingualism, multilingualism, term formation.

The works by B.A.Zhetpisbaev, B.M.Aitbaev and others are devoted to the problems of scientific and methodological support of multilingual education in Kazakhstan [11].

The works of domestic and foreign scientists dealing with the ideas of the interrelated study of language and culture in the structure of the educational system were essential for us to understand the trends in the development of modern higher education in 
the context of polylingualism. These are studies by T.M. Balykhina, A. A. Verbitsky, M.V. Druzhinina, S.A. Dubinko, S.G. Ter-Minasova, N.L. Uvarova, I.I. Khaleeva, L.P. Khalyapina, B. Kh. Khasanova, L.V. Khvedcheni, T.T. Cherkashina, A.N. Shchukina, L.V. Yarotskaya, A. Tabouret-Keller [12], Ch.Schweitzer, E. Simonet [13], Th. Lancien [14], C. Cornaire [15], P. Skehan and others.

\section{Discussion}

Today, both in the domestic and foreign pedagogical literature, an understanding has been established that one of the optimal ways to solve problems of a linguistic nature and intercultural communication as a factor in the formation of multilingual and multicultural competencies is the transition to the principles of multilingual (-language) education in the context of national culture, which allows making the best use of the time allotted for obtaining a bachelor's degree at a technical university.

Multilingual teaching in modern domestic and foreign methodological science is understood as teaching verbal communication in a unified language teaching system based on linguistic, cognitive, socio-cultural, as well as pragmatic experience acquired by students earlier, i.e. when studying pre- vious foreign languages, as well as the native language. This view is based on the psycholinguistic data that new knowledge only remains in memory for a long time if it is integrated into an already existing system of knowledge and is fixed in it.

Multilingualism (manylingualism, polylingualism) is the ability to use two or more languages depending on the social, everyday and professional context, and the levels of language proficiency can be different, both a passive (reading or listening)and active (speaking or writing) level of proficiency. Traditionally, multilingualism is perceived as the knowledge of several separate languages, not united into a certain system. In this case, a multilingual person (a person who speaks several foreign languages) is considered as a carrier of the sum of languages that accumulate linearly in the consciousness of an individual without touching or interacting [16]. Modern researchers point out the ambiguity of this phenomenon and declare the emergence of multilingual competence, which combines all the studied languages into a single system that allows a person to analyze, compare, systematize languages and cultures, develop your strategies for further learning subsequent languages, thereby developing cognitive, cognitive and communication skills of the individual (Figure 1) [17].

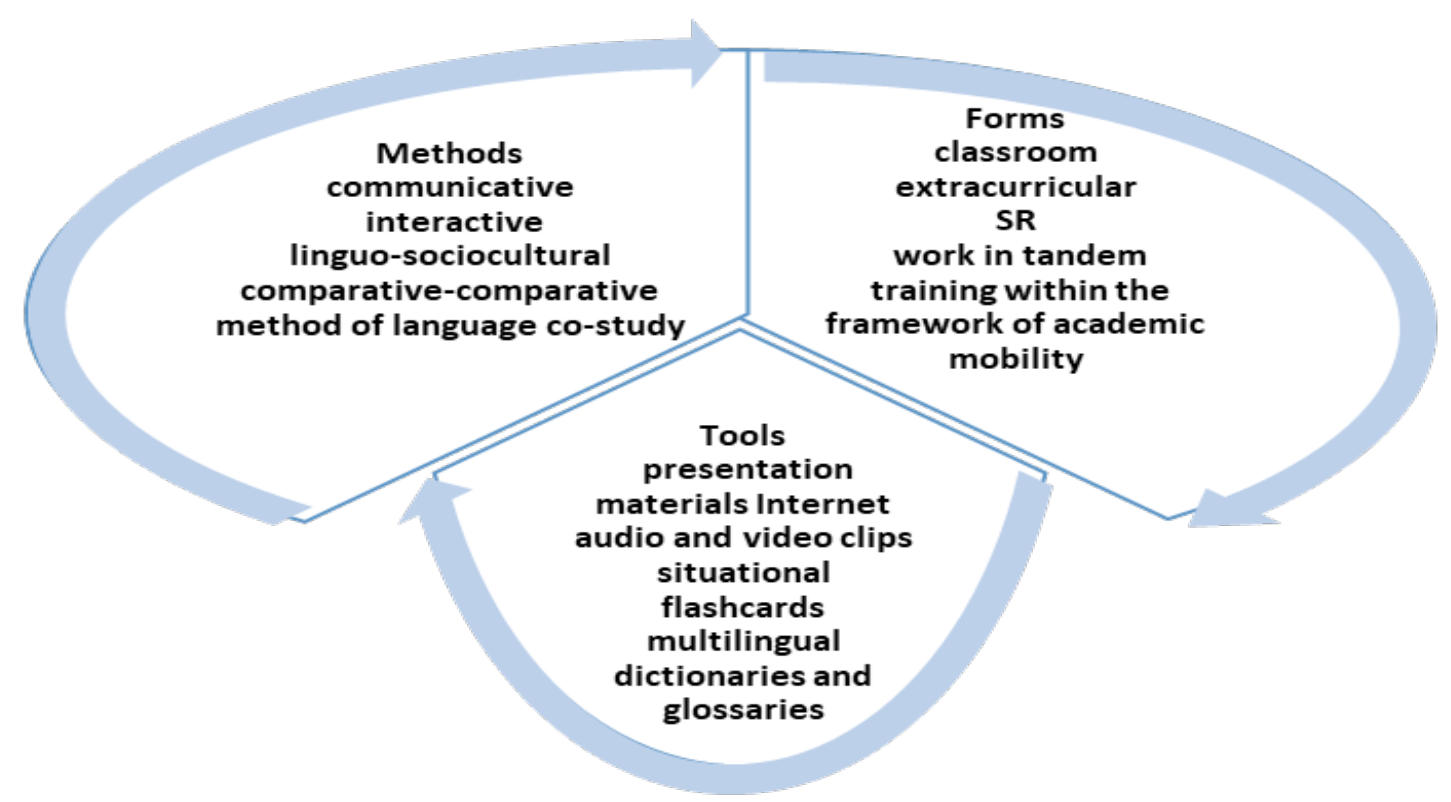

Figure 1 - Main components of multilingual competence 
Knowledge of several foreign languages by an engineer is one of the requirements for registration and certification of engineering personnel with the recognition of their professional qualifications and the assignment of specialist status at the international level. This activity is carried out by national and international communities that develop standards for specialists based on the requirements of employers. The world leaders in the development and application of such standards are FEANI (Europe), CDIO (Canada), WA (USA), AOIR (Russia), etc.

Let us consider the requirements of these organizations for candidates from the point of view of multilingualism. The European Federation of National Engineering Associations FEANI (European Engineer, EurIng) (1951) unites 34 European countries and more than 350 national engineering associations, today FEANI represents the interests of more than 3.5 million professional engineers in Europe. One of the important criteria for assessing the knowledge of a European engineer is "skills of working in an interdisciplinary team, understanding the essence of the engineering profession, communication skills, the responsibility to support competence through continuous professional development". This criterion confirms the fact that an engineer applying for the title of a European engineer must know several foreign languages for successful interaction within a multilingual team and for effective cooperation with international partners in any country of the world [18].

The international project "CDIO Initiative", implemented by leading engineering schools in the USA, Europe, Canada, Great Britain, Africa, Asia and New Zealand, focuses on the practice-forming component of the educational process. The main concept of CDIO (Conceive - Design - Implement - Operate) is to reform the content and effectiveness of engineering educational programs in accordance with the level of development of modern technologies and the expectations of employers. One of the four blocks of engineering competencies includes interpersonal competencies: teamwork; communication (communication in foreign languages: English, languages of industrial partner countries, other languages). As we can see, there is also a clear requirement for knowledge and communication skills in several foreign languages. It implies knowledge of English and the languages of the industrial partner countries or other foreign languages [19].

Having studied the curriculum of one of the participants in the CDIO project of Tomsk Polytechnic University in some areas of bachelor's degree preparation, one can see the existence of the discipline
"Foreign language (English)" for 4 semesters, from the 5th semester the discipline "Professional training in English" is introduced, which ends with credit in the 8th semester, moreover, bachelors are invited to choose a second foreign language (German, French or Chinese) as optional disciplines. Thus, in the conditions of the educational environment of the university, by means of foreign languages, it is possible to approach the international requirements of professional organizations for the accreditation and certification of professional engineers, adding a second foreign language to the curriculum and not stopping the study of English throughout the entire period of study.

According to the research and recommendations of the World Economic Forum [18], the next generation of graduates and employees first of all need to provide competencies corresponding to the professions of the future, namely, multilingualism and multiculturalism; skills of intersectoral communication; customer orientation; the ability to manage projects and processes; work in a high uncertainty mode; the ability to create; work with artificial intelligence; the ability to work with collectives, groups; system thinking; lean production; environmental thinking.

"Organizations of customers" - industrial enterprises in the selection of personnel today distinguish among applicants for the position of an engineer communicative skills and linguistic repertoire. Such organizations have included a readiness to work in a multilingual environment as part of their core competencies for engineers. An example is a German concern Siemens, which wants to hire a specialist with a high level of technical and spoken English, with knowledge of the German language, who is interested in working in a multicultural team, in the position of a commissioning engineer.

Given the role of English in the professional, scientific and academic environment, we can assume that it needs to be integrated into the teaching of special disciplines and reform the teaching of this language in technical universities in the following areas:

- linguistic professional (the language policy of universities aimed at strengthening the training in AL (professional, communicative and academic components) of future specialists and teaching staff; the growth of international academic activity of teachers and scientists of universities (participation in international conferences, international publications); interdisciplinary cooperation of linguists and subject students in the development of professional foreign language training programs in universities; 
- academic (development of academic mobility of students, graduate students and teaching staff; increasing the citation index of Kazakhstani scientists in international databases; attracting foreign teachers on the basis of short-term and long-term contracts; development of international scientific and educational projects; expanding international partnership in the field of science and education; improving the reputation of the university and the quality of education, bringing it in line with international standards;

- economic and political (an increase in the influx of foreign students to universities in Kazakhstan due to the internationalization of curricula; an influx of funds from the export of educational services to the university budget, which will expand the international scientific activities of the university and increase the motivation of teaching staff; attracting grants for international projects; international integration of science, education and production, the growth of the international influence of the state [20].

The universities of Kazakhstan have found various approaches and technologies for the formation of multilingual competence in future engineering specialists. Since 2016, D. SerikbayevEKTU has been conducting training events on the gradual tran- sition to English language of instruction based on the introduction of the technology of level training of students in foreign languages according to the International Standard of Common European Competencies in Foreign Languages CEFR. The main goal of this project was to improve the level and quality of the language training of bachelors through the formation of their communicative, professional, linguistic, pragmatic, discursive and socio-cultural competences. During the project, the following tasks were implemented - students language training in a foreign language based on CEFR (basic English) and then a phased language training in professional English with a gradual introduction of students to the international language exam. The learning outcomes in the 2016-2017, 2017-2018 and 2018-2019 academic years are shown in figures $2,3,4$.

In the sessional period of the 2016-2017 academic year, 1152 students passed the final control, of which $782-1$ year, $370-2$ year. 779 students (69\%), of whom 507 - 1styear, 272 - 2ndyear, have successfully confirmed the level of proficiency in the foreign language and passed to the next level. 373 students $(33 \%)$ remained at the same level of foreign language proficiency, of which $275-1$ styear, 98 - 2ndyear (Figure 2)

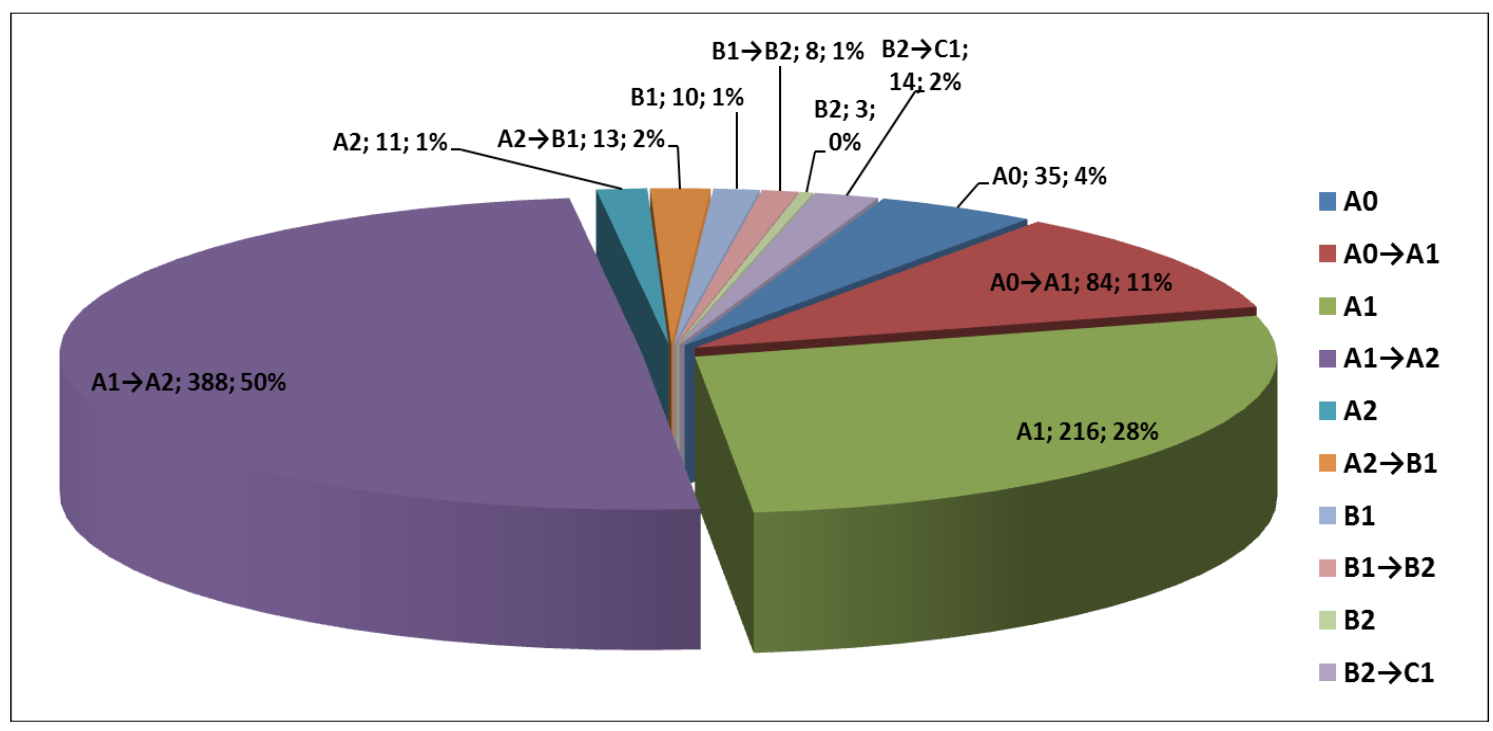

Figure 2 - Results of multi-level education in 2016-2017

In 2017-2018 academic year, 780 1st year students passed the final control. Successfully confirmed the level of proficiency in foreign language and moved to the next level -509 students $(65 \%)$. 271 students $(35 \%)$ remained at the same level of foreign language proficiency - level A0 (total 51): A0-28, A1-23 (45\%), level A1 (total 623): A1 221, A2 - 402 (65\%), A2 (total 75): A2 - 14, B1 61 (81\%), level B1 (total 10): B1 - 3, B2 - $7(70 \%)$, B2 (total 21): B2 - 5, C1 - 16 (76\%) (Figure 3). 


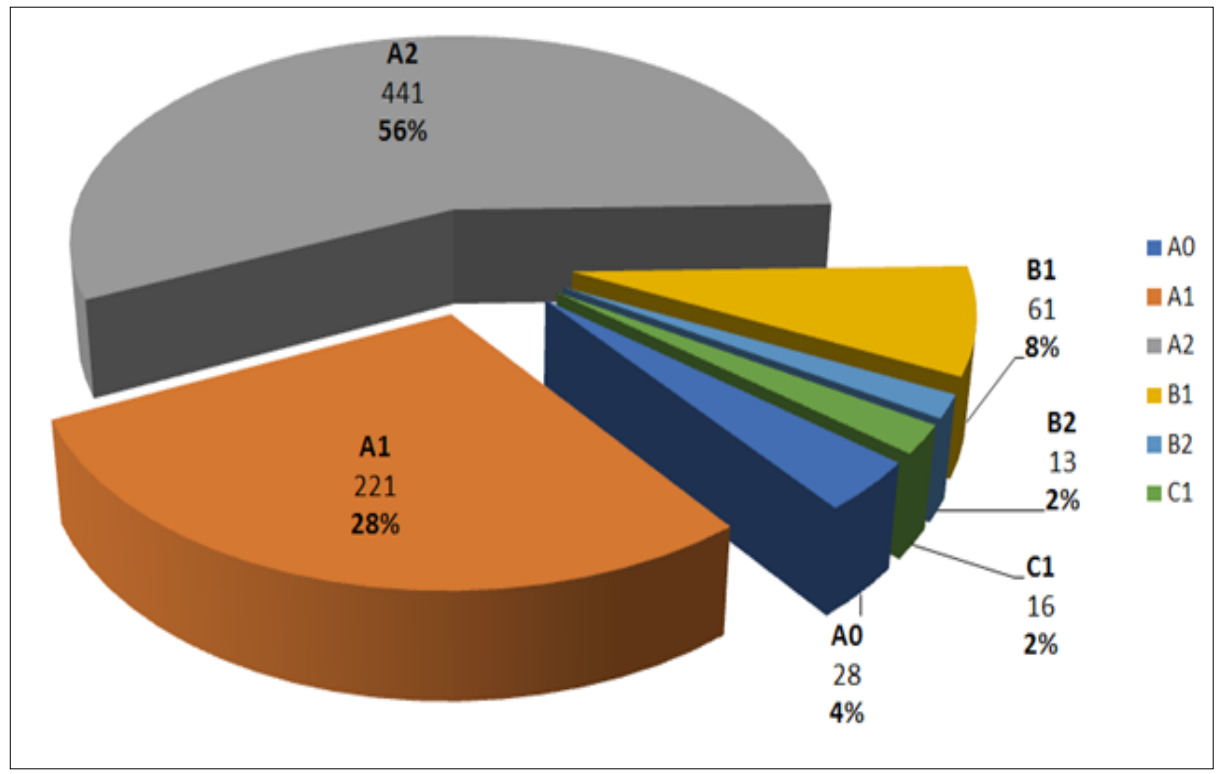

Figure 3 - Results of level education in 2017-2018

In 2018-2019 academic year, 977 1st year students passed the final control. Successfully confirmed the level of proficiency in the foreign language and moved to the next level - 654 students (67\%). 323 students (33\%) remained at the same level of foreign language proficiency - level A0 (total 56): A0-23, A1-33 (68\%), level A1 (total 852): A1 - 289, A2 - 563 (66\%), A2 (total 40): A2 - 8, B1 -32 (80\%), level B1 (total 29): B1 - 3, B2 - 26 (90\%) (Figure 4).

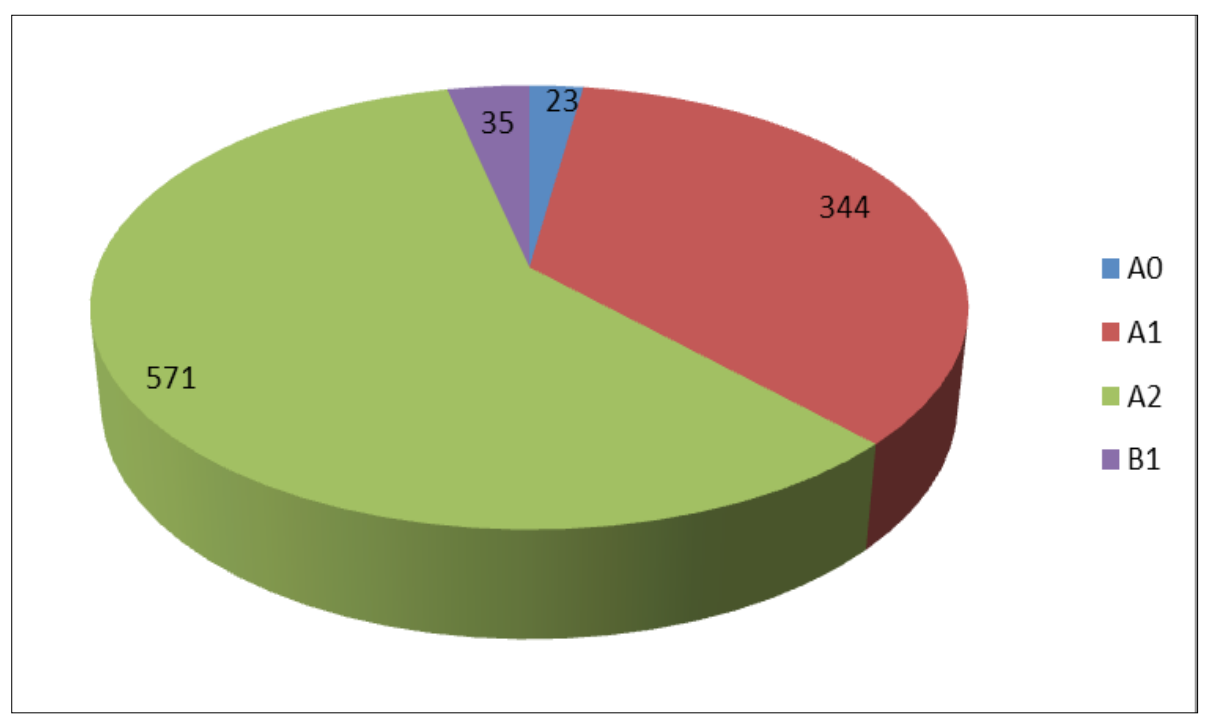

Figure 4 - Results of level education in 2018-2019

Teaching basic English is the first step in preparing students for their professional careers in a multilingual environment.

The level of professional language training assumes that the student has a proficiency level of A2Pre-Intermediate and higher. To develop students' foreign language professional communicative competencies for the active use of the language in the professional sphere at the university, a module (minor) "Language and Communication" was developed, which includes three courses of language training with a total workload of 15 credits (Table 1) [21]: 
- English for Specific Purposes / ESP English for Specific Purposes Writing
- Basic foreign language (German, French, Chinese, Turkish)

All courses are on the D. Serikbayev EKTU Educational Portal.

Table 1 - Map of competencies of a specialist in the module "Language and Communication"

\begin{tabular}{|l|l|}
\hline \multicolumn{1}{|c|}{ Formedkeycompetencies } & \multicolumn{1}{c|}{ Learningoutcomes } \\
\hline $\begin{array}{l}\text { Ability to carry out communicative } \\
\text { activities in a foreign language in } \\
\text { new situations of everyday and } \\
\text { professional communication in oral } \\
\text { and written form }\end{array}$ & $\begin{array}{l}\text { express their communicative intentions with the correct selection and appropriate use of } \\
\text { appropriate language means, taking into account their compliance with the socio-cultural } \\
\text { norms of the target language }\end{array}$ \\
\cline { 2 - 3 } & $\begin{array}{l}\text { apply communication strategies and tactics, rhetorical, stylistic and linguistic norms and } \\
\text { techniques in solving professional problems }\end{array}$ \\
\hline
\end{tabular}

The course «English for Specific Purposes» (https://www.do.ektu.kz/Protected/SDO/Course/ Details.aspx?CourseToTermDistributionsID $=3301$ 9) is intended for future specialists to form their foreign language communicative competence so that students can continue their education in a foreign language environment (English for academic purposes), mastering a profession and pursuing professional activities (English for professional purposes). The learning outcomes on this course should be:

- understanding of professional topics of conversation, news programs, lectures;

- effective communication with native speakers during an interview with a conversation on professional topics;

- understanding of various texts related to the profession;

- description of processes, diagrams, graphs, charts, tables and other documentation of the professional field.

The course "Academic Writing" (https://www. do.ektu.kz/Protected/SDO/Course/Details.aspx?C ourseToTermDistributionsID=30242 ) is intended for the academic environment and involves teaching the construction of an academic text in English, and specific linguistic structures for the implementation of the necessary speech acts: how to give definitions, describe conclusions, convey the views of other scientists, etc. During their studies, students can learn how to conduct written scientific communication in English, which involves developing the ability to build structured, well-grounded and clear arguments, using suitable sources, improving grammar and writing mechanics

The course "Basic foreign language" (https:// www.do.ektu.kz/Protected/SDO/Course/Details.asp $\mathrm{x}$ ?CourseToTermDistributionsID=31115) includes teaching a basic foreign language (level A1-A2), which involves the development students have technical skills and the ability to read and extract information from the text, the study of linguistic forms and speech patterns that allow them to correctly express thoughts in a foreign language, teaching the techniques of working on grammar necessary for constructing an utterance.

As part of the formation of multilingual competence, the following techniques are used in "Language and Communication" module: tasks for comparing different languages and cultures, a virtual business trip to a foreign university in the form of a project assignment, watching videos about cultural and historical objects in different countries, searching for information about great world scientists and their achievements, the use of multilingual dictionaries, glossaries, educational activities involving foreign students, etc.

\section{Conclusion}

The conducted research allows us to draw the following conclusions:

- multilingual competence is the student's ability to learn and then use in practice all the languages studied in a single system, including the forms, methods and means of learning a foreign language;

- in multilingual education, English should play a leading role as the language of international communication, the language of science and business;

- multilingualism as one of the over-professional competencies of an engineering student acts as a process of internal development of a student, his/her cognitive, psychological and sociological knowledge and skills, which significantly expand the possibilities of personal growth and participation in 
international projects of subjects of the educational process;

- multilingualism at a technical university simplifies the mechanisms of preparation, organization or participation of the university in various international events, conferences, regarding the students' potential, which undoubtedly has a positive effect on the international ranking of the university;

- multilingualism is one of the main requirements for registration and certification of engineering personnel with the recognition of their professional qualifications and assignment of the status of a specialist at the international level;

- there is a direct dependence of the level formation of general cultural competencies on the number of learned foreign languages due to the use of various forms and methods of teaching foreign languages with correctly selected content and information content.

This research was funded by the Science Committee of the Ministry of Education and Science of the Republic of Kazakhstan (Grant No.“AP09258780 Germanica in Kazakhstan: language, ethnos, personality in a sociolinguistic, linguistic-personal and lingua-didactic perspective (2021-2023 years))".

This research was funded by the Science Committee of the Ministry of Education and Science of the Republic of Kazakhstan (Grant No. "AP09258780 Germanica in Kazakhstan: language, ethnos, personality in a sociolinguistic, linguistic-personal and lingua-didactic perspective (2021-2023 years))".

\section{References}

Абдукадырова Т.Т. Полиязычие как фактор становления поликультурной личности в условиях глобализации общества // Психолония и образование. - №5 (35), 2017 - С.136-145.

Барышников Н. В. Плюралистическая дидактика языков и культур. Лингводидактические проблемы формирования иноязычных компетенций $\backslash$ Коллективная монография по материалам Международного научно-методического симпозиума «Лемпертовские чтения - ХІХ». - 2017. - С. 16 -22.

Blommaert, J. (2019) Title of host publicationPolitiqueLinguistiquefamiliale / Family language policy: Enjeuxdynamiques de la transmission linguistiquedansuncontextemigratoire / Dynamics in language transmission under a migratory context. - Munich: LINCOM Europa. - 2019. - P. 1-7 ISBN (Print)9783862889303. (article)

Cornaire C. La comprehension orale. CLE International, Paris 1998. -221 p.

Джуринский А. Н. Поликультурное образование в многонациональном социуме. Учебник, 2-е изд. перераб. и доп. М.: Юрайт, 2018. - 252 c. - ISBN 978-59916-4517-1. - URL:https://biblio-online.ru/book/polikulturnoe-obrazovanie-v-mnogonacionalnom-sociume-413230. (книга)

Джуринский А.Н. Интернационализация высшего образования: сотрудничество России и Китая // Гуманитарные науки и образование. - 2020. -т. 11. -№ 1.-. 34-39. (книга)

Евдокимова Н.В. Концепция формирования многоязычной компетенции студентов неязыковых специальностей.

[Текст]. // Монография. Ростов-на-Дону, изд. РГЭУ (РИНХ), 2011, -342 с. (книга)

GrosjeanF. (1989) Neurolinguists, beware! Bilingual is not two monolinguals in one person // Brain and Language. 1989. Vol. 36. p. 3-15. (article)

Халеева И.И. Основытеорииобученияпониманиюиноязычнойречи: (Подгот. переводчиков) / И. И. Халеева. - М.: Высш. шк., 1989. - 236. (книга)

Кутузова В.А., Шапошникова С.О. Перспективы развития инженерного образования: инициатива CDIO: информ-метод. издание. СПб.: Изд-во СПб ГЭТУ «ЛЭТИ». 2012. С. 3-4. (книга)

LancienTh. Le multimedia. CLE International, Paris 1998. 127 p.

Малых Л. М. Введение в мультилингвальное обучение. Принципы сравнения языков: учебное пособие // изд.Флинта. - Москва, 2017. - 109c.

Муравьева Н.Г. Опыт формирования социокультурной компетенции студентов вуза в проектной деятельности (на примере иностранного языка) // Вестник ТюмГУ. Педагогика. Психология. 2013. - С.121-131. (статья)

Прохорова А.А. Многомерные компоненты в структуре мультилингвальной компетенции будущих инженеров // Педагогика. Психология. Социокинетика - 2018. - №2. - С.127-131.

ShabaniK. (2016) Implications of Vygotsky's sociocultural theory for the second language (L2) assessment // Cogent education. 3: Cogent OA. - p. 234-245. (article)

Schweitzer Ch., Simonet E. Methodologie des languesvivantes. Paris: Colin, 1921.-296 p.

Tabouret-Keller A. La question du bilinguisme //« Enfance », 1991 № 4 -p. 271-277.

Царева Е.Е. Мультиязычность как показатель оценки профессиональных качеств инженера: зарубежный опыт / Е.Е. Царева, Р.3. Богоудинова // Вестник Казанского гос. энерг. ун-та. -2017. - № 3 (35). - С. 91-101. (статья)

Wei L. (2016). Epilogue: Multi-competence and the Translanguaging Instinct. The Cambridge Handbook of Linguistic MultiCompetence (pp. 533-543). doi:10.1017/CBO9781107425965.026. (article) 
ЗеленинаТ.И., УтехинаА.Н., Малых Л.М., Мифтахутдинова А.Н. Модель мультилингвального образования в полиэтническом регионе: коллективная монография. Ижевск: Удм. гос. ун-т., 2010. - 243c. (книга)www.feani.org. URL:http://www. feani.org. (датаобращения: 20.08.2017)

Жетписбаева Б.А. Педагогические индикаторы полиязычного образования // Сибирский педагогический журнал. 2008. - С. 269-273. (статья)

\section{References}

Abdukadyrova T.T. (2017)Multilingualism as a factor in the formation of a multicultural personality in the context of society globalization // Psycholonia and education. - No. 5 (35), 2017 - p. 136-145. (article) (in Russian)

Baryshnikov N.V. (2017) Pluralistic didactics of languages and cultures. Linguodidactic problems of the formation of foreign language competences $\backslash$ Collective monograph based on the materials of the International Scientific and Methodological Symposium "Lempert Readings - XIX". - 2017.- p. 16 -22. (in Russian)

Blommaert, J. (2019) Title of host publicationPolitiqueLinguistiquefamiliale / Family language policy: Enjeuxdynamiques de la transmission linguistiquedansuncontextemigratoire / Dynamics in language transmission under a migratory context. - Munich: LINCOM Europa. - 2019. - P. 1-7 ISBN (Print)9783862889303. (article)

Cornaire C. La comprehension orale. CLE International, Paris 1998. -221 p.

Dzhurinskiy A.N. (2018) Multicultural education in a multinational society. Textbook, 2nd edition supplemented and revisedM.: Yurait, 2018. - 252 p. - ISBN 978-59916-4517-1. - URL:https://biblio-online.ru/book/polikulturnoe-obrazovanie-v-mnogonacionalnom-sociume-413230. (book) (in Russian)

Dzhurinskiy A.N. (2020) Internationalization of higher education: cooperation between Russia and China // Humanitarian sciences and education. - 2020. - v. 11. -No. 1.-. 34-39. (book) (in Russian)

Evdokimova N.V. (2011) The concept of multilingual competence formation of students of non-linguistic specialties. [Text]. // Monograph. Rostov-on-Don, ed. RSEU (RINE), 2011, 342 p. (book) (in Russian)

Grosjean F. (1989) Neurolinguists, beware! Bilingual is not two monolinguals in one person // Brain and Language. 1989. Vol. 36. p. 3-15. (article)

Khaleyeva I.I. (1989) Fundamentals of the theory of teaching understanding of foreign language speech: (Training of translators) / I.I. Khaleнеva. - M .: High School., 1989. - 236. (book) (in Russian)

Kutuzova V.A., Shaposhnikova S.O. (2012) Prospects for the development of engineering education: CDIO initiative: informational and methodological publication. SPb.: St. Petersburg ETU "LETI" Publishing house. 2012. p. 3-4. (book) (in Russian)

Lancien Th. Le multimedia. CLE International, Paris 1998. 127 p.

Malykh L.M. (2017) Introduction to multilingual education. Principles of comparison of languages: a tutorial // Edited by Flint. - Moscow, 2017.-109 p.(in Russian)

Muravyova N.G. (2013) Experience in the formation of socio-cultural competence of university students in project activities (on the example of a foreign language) // Bulletin of Tyumen State University. Pedagogy. Psychology. 2013. - p. 121-131. (article) (in Russian)

Prokhorova A.A. (2018) Multidimensional components in the structure of multilingual competence of future engineers // Pedagogy. Psychology. Sociokinetics - 2018. - No2. - p. 127-131.(in Russian)

ShabaniK. (2016) Implications of Vygotsky's sociocultural theory for the second language (L2) assessment // Cogent education. 3: Cogent OA. - p. 234-245. (article)

Schweitzer Ch., Simonet E. Methodologie des languesvivantes. Paris: Colin, 1921.-296 p.

Tabouret-Keller A. La question du bilinguisme //« Enfance », 1991 № 4 -p. 271-277.

TsarevaYe.Ye. (2017) Multilingualism as an indicator of assessing the professional qualities of an engineer: foreign experience / Ye.Ye.Tsareva, R.Z. Bogoudinova // Bulletin of Kazan State Power Engineering University. -2017. - No. 3 (35). - p. 91-101. (article)

Wei L. (2016). Epilogue: Multi-competence and the Translanguaging Instinct. The Cambridge Handbook of Linguistic MultiCompetence (pp. 533-543). doi:10.1017/CBO9781107425965.026. (article)

Zelenina T.I., Utekhina A.N., Malykh L.M., Miftakhutdinova A.N. (2010) A model of multilingual education in a multi-ethnic region: a collective monograph. Izhevsk: Udmurt state university, 2010.- 243p. (book) www.feani.org. URL: http: //www.feani.org. (reference date: 20.08.2017) (in Russian)

Zhetpisbayeva B.A. (2008) Pedagogical indicators of multilingual education// Siberian pedagogical journal. 2008 .- p. 269-273. (article) (in Russian) 